$9-1-2018$

\title{
The Politics of Selecting Chevron Deference
}

Kent H. Barnett

Associate Dean for Academic Affairs \& J. Alton Hosch Professor of Law University of Georgia School of Law, khbarn@uga.edu

Christina L. Boyd

Associate Dean for Academic Affairs \& J. Alton Hosch Professor of Law University of Georgia, clboyd@uga.edu

Christopher J. Walker

Associate Dean for Academic Affairs \& J. Alton Hosch Professor of Law Ohio State University, Moritz College of Law, walker.1432@osu.edu

University of Georgia School of Law

Research Paper Series

Paper No. 2017-21

P bepress

\section{Repository Citation}

Kent H. Barnett, Christina L. Boyd, and Christopher J. Walker, The Politics of Selecting Chevron Deference, 15 J. Empirical Legal Stud. 597 (2018),

Available at: https://digitalcommons.law.uga.edu/fac_artchop/1412

This Article is brought to you for free and open access by the Faculty Scholarship at Digital Commons @ University of Georgia School of Law. It has been accepted for inclusion in Scholarly Works by an authorized administrator of Digital Commons @ University of Georgia School of Law. Please share how you have benefited from this access For more information, please contact tstriepe@uga.edu. 


\title{
The Politics of Selecting Chevron Deference
}

\author{
Kent Barnett, Christina L. Boyd, and Christopher J. Walker*
}

In this article, we examine an important threshold question in judicial behavior and administrative law: When do federal circuit courts decide to use the Chevron deference framework and when do they select a framework that is less deferential to the administrative agency's statutory interpretation? The question is important because the purpose of Chevron deference is to give agencies-not judges-policy-making space within statutory interpretation. We expect, nonetheless, that whether to invoke the Chevron framework is largely driven by political dynamics, with judges adopting a less deferential standard when their political preferences do not align with the agency's decision. To provide insight, we analyze circuit court decisions from 2003 until 2013 that review agency statutory interpretations. Our results-from the largest and most comprehensive database of its kindprovide partial confirmation of our expectations. When courts reviewed liberal agency interpretations, all panels-liberal, moderate, and conservative-were equally likely to apply Chevron. However, when reviewing conservative agency interpretations, liberal panels selected the Chevron deference framework significantly less frequently than conservative panels. Contrary to limited prior studies, we find no evidence of "whistleblower" or disciplining effects when judges of different judicial ideologies comprised the panel. Viewed together, our results provide important implications for the current debate on whether to eliminate, narrow, or clarify Cheuron's domain.

\section{INTRODUCTION}

In recent years there has been a growing call in Congress, in the legal academy, and on the federal bench-largely from those right of center-to eliminate longstanding judicial deference doctrines to federal agency interpretations of law. Legislation has been introduced to amend the Administrative Procedure Act to require courts to review de novo all agency interpretations of statutes and regulations. More recently, the president nominated, and the Senate confirmed, a jurist to the Supreme Court-Neil Gorsuch-who as a circuit judge expressly called into question the constitutionality and wisdom of Cheoron

*Address correspondence to Christina L. Boyd, UGA Department of Political Science, 180 Baldwin Hall, 355 S. Jackson St., Athens GA 30602; email: cLboyd@uga.edu. Barnett is J. Alton Hosch Associate Professor of Law at University of Georgia School of Law; Boyd is Associate Professor of Political Science at University of Georgia; Walker is Associate Professor of Law at The Ohio State University's Moritz School of Law.

We appreciate the excellent feedback from Jonathan Adler, Scott Boddery, Nathan Chapman, Cary Coglianese, Brian Feinstein, Cathy Sharkey, Daniel Walters, participants at the Second Annual Administrative Law New Scholarship Roundtable, and the editors and anonymous reviewers at JELS. 
deference to agency statutory interpretations. Gorsuch's doubts about Chevron deference were front and center at his confirmation hearing,

For more than three decades, Cheuron deference has commanded courts to defer to a federal agency's reasonable interpretation of an ambiguous statute that the agency administers (Cheoron, U.S.A., Inc. v. Nat. Res. Def. Council, Inc. 1984). Courts usually do so under a two-step framework. Under Cheoron's first step, the court asks whether the statutory provision at issue is unambiguous. If so, the inquiry ends, and the court enforces the unambiguous meaning. If the provision is ambiguous, the court proceeds to Chevron's second step and asks whether the agency's interpretation is reasonable. If it is, the agency's interpretation prevails, even if the court believes that the agency's interpretative is not the best interpretation. As opposed to many other standards of review, the Cherron framework limits judicial interpretive primacy and seeks to separate judges from their policy preferences.

Over the years, Cheoron deference has been subject to extensive debate and discussion. Westlaw reports that the Supreme Court's Chevron decision has been cited in more than 80,000 documents in its database, including more than 15,000 cases and nearly 18,000 law review articles and other secondary sources. Indeed, no other administrative law decision by the Supreme Court has received as many citations in the academic literature (Shane \& Walker 2014:475).

Hundreds of legal scholars, including empiricists, have addressed Chevron's theoretical foundations, its legal and constitutional status, and its doctrinal scope. A number of empirical scholars have examined Chevron and case outcomes, either through important descriptive accounts of how Supreme Court and circuit court cases use Chevron (Eskridge \& Baer 2008; Barnett \& Walker 2017a; Pierce 2011; Schuck \& Elliot 1990; Merrill 1992; Kerr 1998) or through more systematic empirical examinations of the political dynamics of judicial decision making in these courts in light of Chevron (Cross \& Tiller 1998; Czarnezki 2008; Miles \& Sunstein 2006; Sunstein et al. 2004). Among other significant insights, this empirical literature reveals that where judges' partisanship aligned with the direction of the agency outcome, those judges were more likely to affirm the agency's interpretation.

Despite the mountain of Cheoron-related scholarship, we continue to have little concrete evidence on when and why judges choose to apply the Cheoron framework versus applying some less deferential standard. The judicial choice of whether to apply the Chevron doctrine or some less deferential standard is an important threshold question worthy of additional attention.

First, the choice of the review standard-Chevron or otherwise-lays the path toward the outcome in the case. Standards that demand a high degree of deference to the initial decisions should lead to higher rates of affirmance of those decisions than standards that give judges more discretion to insert their own preferences. The Chevron doctrine, when faithfully applied, unquestionably cabins judicial discretion and demands a high degree of adherence to agency statutory interpretation decisions. As a result, judges may look to apply less deferential standards of review during times when they are likely to disagree with the agency. A standard like the Skidmore v. Swift (1944) doctrine, for example, permits judges not to defer to the agency's interpretation if that 
interpretation is not persuasive. This less deferential standard undoubtedly eases a judge's path toward overturning the agency interpretation and, as such, is critical to study. And, of course, plenary or de novo review shifts interpretive power even further toward courts and away from federal agencies. As Tribe once argued, "[j] udicial authority to determine when to defer to others ... is a procedural form of substantive power" (1978:iv).

Second, and more generally, studying threshold questions in judicial behavior is critical for developing a broader understanding of judicial behavior. Epstein and Knight argue that empirical explorations of judging "should not begin and end with examinations of the vote, as they have for so many years. Rather, we must explore the range of choices that contribute to the development of law" (1998:185). Although a handful of empirical studies have tackled important threshold questions-for example, those related to standing (e.g., Staudt 2004; Pierce 1999; Rowland \& Todd 1991), standards of review in constitutional law cases (e.g., Baldez et al. 2006), and certiorari at the Supreme Court (e.g., Black \& Owens 2009; Caldeira \& Wright 1988)-most empirical work continues to focus on the outcomes and merits. Studying the choice to apply or avoid Cheoron promises not only to provide substantive insight into judicial review in administrative law cases but also the iterative and agenda-setting nature of judicial behavior.

To provide the first systematic empirical evaluation of this threshold Cheoron question, we use the Barnett and Walker (2017a) data to analyze published circuit court decisions from 2003 through 2013 reviewing agency statutory interpretations. Our results confirm longstanding intuition and earlier, more limited empirical studies: judges do not consistently apply Chevron. Our findings offer some surprising insights into Cheuron's political dynamics. When courts review liberal agency interpretations, all panels-liberal, moderate, and conservative-are nearly equally likely to apply Cherron, as opposed to some lesser deference standard or no deference at all, but when reviewing conservative interpretations, liberal panels apply Chevron significantly less frequently than conservative panels. Contrary to some prior work examining outcomes and utilizing smaller datasets, we find no evidence of "whistleblower" or disciplining effects when judges of different judicial ideologies comprised the panel.

As we detail further in the discussion section, our findings have important implications. Which judges are and are not consistently applying the Cheoron framework may be our most intriguing findings. Despite growing Republican skepticism of Cherron, ${ }^{1}$ our results reveal that liberal judges are the ones who are less likely to invoke Chevron deference $^{2}$ than their conservative colleagues, at least with respect to conservative agency statutory interpretations. This finding likely means that notable prior empirical studies reporting that judges' political preferences drive case outcomes when utilizing the Cheoron doctrine underreport the political dynamics at play in this arena. Our

\footnotetext{
${ }^{1}$ Walker (2018) provides a review of the judicial and scholarly criticism of Cherron to date.
}

${ }^{2}$ Throughout this article, we use a variety of verbs-for example, invoke, choose, select, apply-to refer to the threshold, premerits decision of circuit courts to utilize the Cheoron deference framework to review an agency's statutory interpretation instead of some less deferential standard. 
results also provide critical empirical insights into Chevron's political dynamics that should inform the current debate on whether to eliminate, narrow, or clarify Chevron's domain.

\section{Judicial Attitudes and Chevron Deference}

Legal scholars frequently presume that legal doctrine leads judges, despite their political ideology, to apply neutral principles to reach uniform results (the "legal model"), but numerous empirical studies find that appellate judges' policy preferences significantly predict judicial behavior (the "attitudinal model") (e.g., Barnes Bowie \& Songer 2009; Hettinger et al. 2006; Epstein et al. 2013; Sisk et al. 1998; Miles \& Sunstein 2006; Segal \& Spaeth 2002). The two models can work in tandem, where doctrine limits judges from achieving their preferred policy outcomes in some, but not all, cases (Czarnezki 2008). The clearer (and thus more limiting) the doctrine, the more likely that judges will comply (Staudt 2004). In other words, the truth likely rests somewhere between the legal and attitudinal models.

After all, all legal doctrine, by identifying relevant principles and framing the points of debate, cabins judicial discretion to some degree (Lindquist \& Cross 2005). Most doctrine seeks to provide substantive principles to resolve legal issues. However, deference doctrines do something different from and in addition to substantive legal doctrine. They command judges to defer to other actors' decisions of fact or law (such as states, agencies, juries, or other judges) based on others' sovereign interests or institutional advantages.

Compared to other deference doctrines, Chevron deference is unique by having a self-stated purpose of separating judges from policy preferences. When reviewing conservative or liberal agency statutory interpretations, courts are to enforce only clear congressional intent after using traditional tools of statutory construction (Step 1) and leave the policy-making space inherent in ambiguous statutory provisions to more expert and politically accountable agencies (Step 2). By removing courts from the inherent policy making in interpreting ambiguous statutory provisions de novo, Chevron, at least in theory, renders it more likely that judicial panels of differing political and judicial ideologies across the country will reach uniform results.

\section{A. Prior Empirical Work: Judicial Attitudes and Case Outcomes After Applying Chevron}

Prior empirical studies have attempted to address whether, when judges apply the Cherron deference framework, they do so uniformly to all agency interpretations or differently to reach their presumed policy preferences. In other words, they have attempted to determine how successful Chevron is in imposing a legal model on judicial review of agency statutory interpretation by assessing case outcomes. Indeed, despite hopes that Cherron would separate judges from their policy preferences in making decisions, these studies have reported evidence to the contrary. This work suggests that Cherron, once applied, is used differently based on the ideological circumstances of the case and goals of the reviewing judges. 
Perhaps most famously in this arena, Cross and Tiller (1998) examined approximately 170 DC Circuit Cheuron cases decided between 1991 and 1995. As expected, the authors find strong evidence of policy convergence in case outcomes applying Cheuron deference. Where the panelists' partisanship aligned with the direction of the agency outcome, those judges were more likely to affirm the agency's interpretation. Later empirical work that also considers outcomes confirms this ideological congruence effect for courts of appeals judges' review of administrative agencies (Czarnezki 2008; Miles \& Sunstein 2006; Sunstein et al. 2004).

\section{B. Judicial Attitudes and the Threshold Chevron Question}

Despite the clear interest of empirical scholars in examining the potential intersection of judicial ideology and Chevron, prior work in this area has exclusively focused on outcomes. If judicial ideology also affects whether courts apply the Chevron deference framework at all, it is likely that we have been underestimating the political dynamics at work in this arena of judicial decision making.

Indeed, we expect that similar attitudinal considerations will guide judicial behavior prior to a court's application of Cheuron's two steps and the ultimate outcome of the judicial review. In other words, the ideological congruence between the panel judges' preferences and the agency's statutory interpretation should increase the likelihood that judges will apply the Chevron framework, instead of a less deferential framework (such as Skidmore v. Swift [1944] deference) or no deference at all. ${ }^{3}$

By concentrating on the appropriate deference regime when reviewing agency statutory interpretations (as opposed to mere outcomes), judges may be best able to achieve two goals: (1) align the outcome with their policy preferences, and (2) shroud their chosen outcome under the cover of neutral principles of judicial review that appear independent from the merits. For instance, under the attitudinal model, we would expect conservative judges to apply the Cheorom framework to conservative agency statutory interpretations. Cheoron deference gives agencies space to interpret ambiguous statutory provisions and limits courts to considering whether agencies' interpretations are merely reasonable (not correct or the best interpretation). Within this Cheuron space for agencies, conservative judges can increase the likelihood of aligning their policy preferences with the outcome of the decision and do so within a framework that conspicuously limits the appearance of judicial interference. Likewise, we would expect liberal judges not to apply Cherron when reviewing conservative agency interpretations. By applying less deferential Skidmore deference or de novo review, courts proceed under a judicial review regime in which they retain

\footnotetext{
${ }^{3}$ The Supreme Court has left lower courts with some room in determining when Cheoron applies. For instance, United States v. Mead Comp. (2001) came close to providing a "force-of-law" rule, but it is sufficiently open-ended to leave courts discretion. Moreover, Barnhart $v$. Walton (2002) relied, in dicta, on an open-ended contextual approach and undermined even some of the certainty that many had assumed adhered in Mead (that rulemaking and formal adjudication had the force of law and thus would always receive Cheorom deference). Moreover, the new major questions doctrine articulated in King \%. Burwell (2015), with its vagaries, provides lower courts additional room (Barnett \& Walker 2017b).
} 
interpretive primacy to provide a definitive and best interpretation of the statutory language at issue. Within these more judicially powerful review schema, courts can justify interpreting statutes, contrary to agencies' favored readings, consistently with their preferences.

By selecting the appropriate deference regime and obscuring ideological congruence, judges can obtain the benefits that the legal model provides while limiting its costs. The legal model has significant purchase on the legal profession. The belief that neutral rules and precedent dictate outcomes and limit judicial discretion are central to notions of judicial identity and judicial oversight. Relatedly, adhering to neutral rules and precedent is central to judicial reputation and can save decision-making resources (Staudt 2004). By choosing among deference regimes, judges can purport to follow neutral rules and obscure the alignment of their policy preferences and decisions. Deference regimes, thus, provide an avenue for judges to obtain the reputation and professional benefits of the legal model with the personal benefits of the attitudinal model.

Although we are the first empirical study to examine judicial application of the Chevron framework, other studies have considered judicial decision making on other threshold questions-that is, those that do not directly concern the substantive merits of the parties' underlying dispute. The answers to these threshold questions provide an avenue for judges to align their preferences with case outcomes. For example, prior studies have reported that judges' political preferences have significant room to operate when applying standing doctrine (especially if judicial oversight by higher courts is relatively rare) (Staudt 2004; Pierce 1999; Rowland \& Todd 1991) or selecting standards of review for equal protection claims (Baldez et al. 2006).

Based on this theory and these prior studies on threshold questions, we hypothesize that reviewing appellate court panels will be ideologically minded when choosing whether to apply the Chevron deference framework or avoid it. Stated formally:

Hypothesis 1a: When an agency interprets the relevant statute in a conservative (liberal) direction, conservative (liberal) circuit court panels should be more likely to apply the Chevron deference framework in their judicial review.

Hypothesis 1b: When an agency interprets the relevant statute in a liberal (conservative) direction, conservative (liberal) circuit court panels should be less likely to apply the Chevron deference framework in their judicial review.

\section{CheVRon WhistLeblowers?}

Even if three-judge panels of all conservative or all liberal judges apply (or ignore) the Chevron framework to further their political preferences, do mixed panels--where one judge has different political preferences than the other two-act differently? We expect that they would.

In numerous areas, researchers have reported evidence of "group polarization." This phenomenon leads groups discussing a problem to "coalesce, not toward the middle of antecedent dispositions, but toward a more extreme position in the direction indicated by those dispositions" (Sunstein 2000:74-75). Prior studies have reported findings of group polarization in the federal judiciary in a number of legal matters (Sunstein et al. 
2004), including findings that extend collegial effects beyond ideology to areas such as the sex and race of the judges (Boyd et al. 2010; Cox \& Miles 2008).

The presence of a judge with opposing political preferences on a three-judge panel, however, leads to a "large disciplining effect" in which the majority's ruling will align less often with its political preferences, despite the majority's ability to rule as it pleases (Sunstein et al. 2004:306). This disciplining effect may arise from the minority judge's counterarguments that win over her colleagues or from the minority judge's presence as a "whistleblower," who expressly or implicitly threatens to alert parties, higher courts, and policymakers to the majority's disobedience to precedent. In reviewing the relevant literature on these "panel effects," Stephenson (2010:308) has explained that "judges on courts of appeals panels sometimes make concessions to their colleagues," including that "minority judges will sometimes go along with the majority" ("majority effect"), and that "majority judges will sometimes make concessions to the minority judge on the panel" perhaps to avoid a separate dissent ("diversity effect").

Cross and Tiller's (1998) study of the DC Circuit provides preliminary evidence of a whistleblower effect in Chevron cases. As the authors find in their analysis of outcomes, the presence of a judge of a different ideology encouraged the judges in the majority to be more likely to defer to the agency's interpretation. Notably, these whistleblower findings are consistent with both the legal and attitudinal models. The judge of a different ideology may affect the majority by convincing the judges to follow precedent by reasoning with them in a lawyerly fashion, thereby furthering the legal model's understanding of how precedent and legal argument restrains judicial decision making. Or the judge may affect the majority by threatening to call attention to the majority judges' disobedience to precedent, thereby exacting a cost under the attitudinal model for judges who, despite precedent, would prefer to align their decisions with their preferences. Under this latter view, the whistleblower provides a monitoring function for the en banc court of appeals, the Supreme Court, and Congress to ensure compliance with precedent and limit personal preferences (Staudt 2004).

Based on prior studies and their consistency with leading theoretical models, we expect that panels with a whistleblower would be more likely to apply the Chevron deference framework than panels of ideologically homogenous judges. More formally:

Hypothesis 2: The presence of an ideological minority on a panel should increase the likelihood that a panel will apply the Chevron deference framework.

While whistleblowers might create a powerful pull toward Cheyron in all circumstances, a more nuanced story reintroduces policy preferences into the mix. In particular, it may be that whistleblowers have a positive effect on Cheuron's application only when the majority on the panel is not in ideological congruence with the agency's interpretation. As Cross and Tiller argue, this theory "postulates that there should be an effect when a 2-1 majority is in conflict (in terms of its partisan policy preferences) with the agency over policy outcomes, rather than when the 2-1 majority is in agreement with the agency's policy choice" (1998:2171). When the majority's and the agency's preferences conflict, the whistleblower is most likely to encourage the majority's adherence to 
doctrine (even if it renders it more likely that the agency will prevail) by either reasoning with the majority or threatening to publicize its disobedience.

Prior whistleblowing studies confirm the ideologically-driven nature of the whistleblower effect, at least with respect to outcomes. Notably, Cross and Tiller find that in cases where the panel is politically unified and disagrees with the agency's decision, the panel defers to the agency only 33 percent of the time. When the panel is split 2-1, with the majority disagreeing with the agency's decision, the rate of deference rises to 62 percent. As the authors argue, "the presence of a whistleblower makes it almost twice as likely that doctrine will be followed when doctrine works against the partisan policy preferences of the court majority" (1998:2172). Miles and Sunstein (2006), studying the judicial review of EPA and NLRB decisions, find that politically mixed panels dampen ideological effects. Revesz's (1997) examination of the DC Circuit's review of EPA decisions reveals that panels of three Republican-appointed judges were more likely to reach stereotypical ideological results than panels with one or two Republican-appointed judges. Notably, Revesz did not find a similar effect for Democrat-appointed judges. Sunstein et al. (2004) also report a political whistleblowing effect in their study of courts of appeals cases. Like Revesz, that effect varied depending on whether the whistleblower was a Republican or a Democrat. With the former, a Democrat majority was 11 percent more likely to issue a conservative ruling than an all-Democrat panel, but with the latter, a Republican majority was only 5 percent more likely to issue a liberal ruling than an all-Republican panel.

We expect a similar political congruence whistleblower effect in the context of the decision whether to apply or avoid Cheoron:

Hypothesis 3: The presence of an ideological minority on a panel should increase the likelihood that a liberal (conservative) majority panel will apply the Chevron deference framework following a conservative (liberal) agency interpretation.

\section{DATA}

To examine empirically whether circuit courts apply the Cheoron deference framework in their review of agency interpretations, we utilize Barnett and Walker's (2017a) newly collected set of relevant cases decided from 2003 to 2013 in federal circuit courts. ${ }^{4}$ The data include all published opinions in which the court explicitly cited and discussed Chevron and/or Skidmore and proceeded to review an agency's interpretation of a statute. ${ }^{5}$ We

\footnotetext{
${ }^{4}$ See Barnett and Walker (2017a) for more detail on the underlying database and coding methodology. Note that while Barnett and Walker (2017a) provide important descriptive insights into the data, they do not incorporate political variables or estimate statistics to test hypotheses.

${ }^{5}$ Within the 1,449 cases in our analyzed data, 1,401 cited Chevron while 48 cited only Skidmore (but not Chevron). Descriptively, over 25 percent of the cases in our data that cite Chevron ultimately do not use Chevron deference. Our statistical results reported below do not substantively change when we exclude the cases citing only Skidmore (but not Chevron) from the analysis.
} 
Table 1: Summary Statistics for Analyzed Data

\begin{tabular}{|c|c|c|c|c|c|c|}
\hline & \multicolumn{3}{|c|}{ Liberal Agency Interpretation } & \multicolumn{3}{|c|}{ Conservative Agency Interpretation } \\
\hline & Mean & $\begin{array}{l}\text { Stnd. } \\
\text { Dev. }\end{array}$ & $\operatorname{Min}-\operatorname{Max}$ & Mean & $\begin{array}{l}\text { Sind. } \\
\text { Dev. }\end{array}$ & $\operatorname{Min}-\operatorname{Max}$ \\
\hline Chermon deference & 0.724 & 0.447 & 0 to 1 & 0.719 & 0.450 & 0 to 1 \\
\hline Panel ideology & 0.07 & 0.23 & -0.42 to +0.54 & 0.06 & 0.22 & -0.50 to +0.54 \\
\hline Partisan unified panel & 0.28 & 0.45 & 0 to 1 & 0.27 & 0.44 & 0 to 1 \\
\hline Panel variance & 0.60 & 0.33 & 0 to 1.05 & 0.56 & 0.30 & 0 to 1.05 \\
\hline Rulemaking & 0.45 & 0.50 & 0 to 1 & 0.35 & 0.48 & 0 to 1 \\
\hline Informal interpretation & 0.36 & 0.48 & 0 to 1 & 0.20 & 0.40 & 0 to 1 \\
\hline Adjudication & 0.18 & 0.39 & 0 to 1 & 0.45 & 0.50 & 0 to 1 \\
\hline Subject matter-environment & 0.20 & 0.40 & 0 to 1 & 0.12 & 0.33 & 0 to 1 \\
\hline Subject matter-employment & 0.11 & 0.32 & 0 to 1 & 0.04 & 0.19 & 0 to 1 \\
\hline Subject matter-immigration & 0.02 & 0.15 & 0 to 1 & 0.46 & 0.50 & 0 to 1 \\
\hline Subject matter-entitlements & 0.05 & 0.23 & 0 to 1 & 0.11 & 0.32 & 0 to 1 \\
\hline Independent & 0.25 & 0.43 & 0 to 1 & 0.08 & 0.26 & 0 to 1 \\
\hline Year & 5.12 & 3.52 & 0 to 10 & 4.78 & 3.10 & 0 to 10 \\
\hline
\end{tabular}

exclude from our analysis 126 cases in which the agency's interpretation could not be classified as either liberal or conservative and 38 cases that were decided en banc. The resulting data include 1,449 cases. $^{6}$ Although these data allow us to speak confidently about how circuit courts apply administrative law deference doctrines, selection effects in how cases reach appellate courts limit our ability draw broader inferences about the legal system (e.g., Eisenberg \& Heise 2015; Eisenberg \& Schwab 1989; Priest \& Klein 1984).

Our dependent variable is Chevron Deference. Coded dichotomously, the variable has a value of 1 if the deciding circuit panel utilized the Chevron deference framework in its review ${ }^{7}$ and 0 if it avoided applying Chevron and instead applied a lower level of deference to the agency, including Skidmore deference or no deference at all. ${ }^{8}$ Summary statistics for Chevron Deference and all other variables are reported in Table 1.

To ease the assessment of whether panels are ideologically motivated in applying Cheuron, we divide our data into two: cases in which the agency interpreted the relevant statute in a liberal direction (Liberal Agency Interpretation) and cases in which the agency

\footnotetext{
${ }^{6}$ For ease of reference, we refer to these as "cases," but one judicial opinion may have multiple agency statutory interpretations under review. Each agency statutory interpretation under review is considered a separate case. To account for the lack of independence among observations derived from a shared underlying opinion, our statistical modeling clusters the standard errors on opinions.
}

\footnotetext{
${ }^{7}$ Our measurement of Cheuron Deference incorporates all instances where the court utilizes the two-step Cherron deference framework in reviewing the statutory interpretation. This includes inquiries that are resolved under Chevron's Step 1 and those that continue to Step 2 for their final resolution. We leave it to future work to explore the judicial behavior and political dynamics that may be present in the application of Cheoron during the two steps.

${ }^{8}$ Cases in which the circuit panel's opinion does not ultimately decide which deference standard should apply are coded as 0. Excluding these cases (fewer than 100 total) from our analysis does not alter the key results reported below.
} 
interpreted the statute in a conservative direction (Conservative Agency Interpretation). ${ }^{9}$ In coding the ideological direction of agency interpretations, we closely follow Eskridge and Baer (2008). ${ }^{10}$ We coded agency interpretations as liberal if the agency favored the interests of parties like civil rights plaintiffs, debtors, employees, immigrants, and taxpayers. Agency interpretations are coded as conservative when they favor interests like alleged discriminators in civil rights cases, employers, criminal prosecutors, companies accused of environmental pollution, and tax collectors. ${ }^{11}$ Agency interpretations that are ideologically neutral are excluded from the analysis.

Panel Ideology is necessary to assess whether panels apply the Chevron deference framework in ideologically motivated ways. To measure Panel Ideology, we utilize the Judicial Common Space (JCS) ideology scores (Epstein et al. 2007; Giles et al. 2001). Derived from the Poole and Rosenthal NOMINATE Common Space ideal point scores for senators and the president, JCS scores range from -1 (most liberal) to +1 (most conservative) and are assigned to judges based on the strong norms of senatorial courtesy in the appointment process. Panel Ideology is computed as the average JCS score of all circuit court judges sitting in the majority in a case. Within our data, Panel Ideology ranges from -0.502 to +0.538 .

To capture the potential effects of a whistleblower, we adopt two alternative measures. The first, Partisan Unified Panel, captures whether the partisanship on the panel is unified (coded 1) or divided (coded 0 ). Unified panels include all Republicans or all Democrats, whereas divided panels include two partisan allies and one outsider (i.e., two Republicans and one Democrat or two Democrats and one Republican). The alternative variable for capturing the potential effect of an ideological foe on a panel is Panel Variance. This variable is calculated as the absolute distance between the most conservative and most liberal judges on a panel and is measured using the panelists' JCS scores. The variable ranges from 0 to 1.052 in our data, where a score of 0 means that all judges on the panel have identical JCS scores.

In addition to these attitudinal variables, we also account for relevant agency and case variables in our statistical modeling. This includes the agency's format or process for engaging in statutory interpretation, which is captured via three dichotomous variables:

\footnotetext{
${ }^{9}$ Subdividing our data into liberal and conservative agency interpretations allows us to avoid the need to include multiple double and triple interactions in our statistical modeling and eases the interpretation of the results. At the same time, however, we recognize that the cases in these liberal and conservative agency interpretation groups are not randomly assigned to those groups; rather, they are generated through distinct processes and case factors. While we statistically control for some of these (e.g., subject matter, agency format), we cannot measure or observe all the factors that lead to the different agency interpretations. As such, this article seeks to avoid directly comparing the substantive results that yield from the two datasets to one another and cautions the reader to avoid doing so as well.
}

\footnotetext{
${ }^{10}$ Unlike Baer and Eskridge (2008), we did not identify cases as "mixed" if one judicial decision upheld at least one conservative interpretation and one liberal interpretation. For example, if a court upheld one agency liberal interpretation and one conservative interpretation, Baer and Eskridge would code the entire decision once and identify it as "mixed." In contrast, we coded the two separate interpretations as their own "cases," marking one as liberal and the other as conservative.
}

\footnotetext{
${ }^{11}$ See the Appendix of Eskridge and Baer (2008) for full details on the coding of this variable.
} 
Rulemaking, Informal Interpretation, and Adjudication. An agency's format is coded as Rulemaking if it uses formal rulemaking, informal "notice and comment" rulemaking, or Federal Energy Regulatory Commission (FERC) rulemaking proceedings. Agencies are coded as using Adjudication if they rely on an adversarial hearing or adjudication. Finally, agencies are coded as using Informal Interpretation if their statutory interpretation arises from non-rulemaking and non-adjudication settings such as settlements, licensing or permit decisions, and agency manual or policy statements. Based on the Supreme Court's doctrinal suggestions that the Cheoron deference framework will apply to formalized agency interpretations, we expect that courts reviewing agencies with a Rulemaking format are more likely to use the Chevron deference framework than courts reviewing agencies using Adjudication or Informal Interpretation. Relatedly, we also expect that courts reviewing agencies with an Informal Interpretation format are less likely to use the Cheoron deference framework than courts reviewing agencies using Adjudication or Rulemaking.

We also measure the subject matter of the agency interpretations. While nearly 30 different subject matters emerge from our data, a few areas dominate. These include immigration, environment, entitlement programs, and employment. We expect that courts would be less like to apply the Chevron framework faithfully when they review agency statutory interpretations concerning politically salient and divisive matters, such as employment, civil rights, and labor unions. For subject matters that have lower political salience and that rely on technical or scientific expertise, we expect that courts will be more likely to apply the Cheoron deference framework faithfully.

Additionally, we control for Independent Agency. Based on Barnett and Walker (2017a), this variable is coded as 1 if the agency is an independent agency and 0 if it is an executive agency. Cheoron deference is grounded on, among other things, political accountability because policy choices, made in the face of ambiguous statutory language, are appropriately resolved by politically accountable agencies (Cherron, 467 U.S. at 865-66). By design, independent agencies are less politically accountable than executive agencies because, among other things, the heads of independent agencies are insulated from the oversight of the president, who is elected. We expect, accordingly, that reviewing circuit courts will be less likely to use the Cheoron deference framework when reviewing independent agencies.

We also control for the circuit and year in which the cases was decided. Following Cross and Tiller, Year is coded as 0 for the first year in our data and "is intended to capture the possibility that the Chevron doctrine has grown weaker over time" (1998:2170).

\section{Results}

To examine statistically when courts apply the Chevron deference framework, we estimate logistic regression models. ${ }^{2}$ To ease the interpretation of our results and avoid

\footnotetext{
${ }^{12}$ We obtain statistically and substantively similar results when we estimate a linear probability model (LPM) instead of a logistic regression model.
} 
unnecessary double and triple interaction terms, we separately estimate our results for cases with Liberal Agency Interpretations and Conservative Agency Interpretations. Table 2 contains the results. ${ }^{13}$

The results, reported in Table 2, allow us to assess our key attitudinal hypotheses. We begin first with Hypothesis 1. Recall that this hypothesis anticipates that Chevron deference will be most likely during times of ideological congruence between the agency's decision and the circuit court panel's ideological preferences. In other words, conservative panels will be more likely to apply the Chevron deference framework to the agency's interpretation when that interpretation is itself conservative but will be less likely to utilize Cheoron deference, and instead use a lower level of deference, when the agency provides a liberal interpretation, and vice versa for liberal panels.

To test this expectation, we look to the Panel Ideology variable in Table 2. We expect to see a positive and significant effect on the Panel Ideology variable (which runs from most liberal to most conservative) when there is a Conservative Agency Interpretation and a negative and significant effect when there is a Liberal Agency Interpretation. As the results in Table 2 reveal, we find partial support for this. In times of a Liberal Agency Interpretation, Panel Ideology does not have a statistically significant effect on whether the panel uses the Cheoron deference framework or something lower. However, when there is a Conservative Agency Interpretation, the results indicate a statistically significant effect.

Figure 1 provides more substantive insight into these Panel Ideology-Agency Interpretation direction results. Subfigure (a) confirms that when an agency has a liberal interpretation of the statute, the ideological preferences of the reviewing panel have little effect on whether the panel will apply the Chevron framework. Indeed, after holding other variables at their mean and modal values, the likelihood of the court affording the agency's liberal interpretation Cheoron-level deference is approximately 95 percent regardless of whether the reviewing panel is liberal, moderate, or conservative.

When we examine the results from the conservative agency interpretation dataset in Figure 1(b) we see a very different story. During times where the agency has issued a conservative interpretation of the statute, conservative circuit panels continue to apply the Cheuron framework readily. As the panels move in a more liberal direction, the likelihood of relying on the Chevron deference framework falls. As the figure indicates, the likelihood of the most liberal panel in our data using the Cheuron deference framework following a conservative agency interpretation of the statute is as low as 74 percent. By contrast, the likelihood of the most conservative panel in the data

\footnotetext{
${ }^{19}$ Using circuit court sex discrimination case data from 1995-2002, Kim (2009) provides evidence that panel effects may emerge based on certain strategic, hierarchical considerations. Our unit of analysis (panel decision) and dependent variable (Cheoron Deference) are imperfect vehicles for fully testing Kim's strategic hierarchical theory (which focuses on individual judge merits votes and whether judges behave counterideologically). We note as a preliminary matter, however, that our statistical modeling reported herein is robust to the addition of strategic, hierarchical variables Carcuit En Banc Median Ideology (measured as the median ideology of the circuit's active judges in a year) (Epstein et al. 2007) and U.S. Supreme Court Median Ideology (measured as the median ideology of the Supreme Court in a year) (Epstein et al. 2007). The addition of these variables does not affect the statistical or substantive effects of our main variables, nor do these variables achieve statistical significance themselves.
} 
Table 2: Logistic Regression Estimates for Whether the Reviewing Panel Uses the Chevron Deference Framework

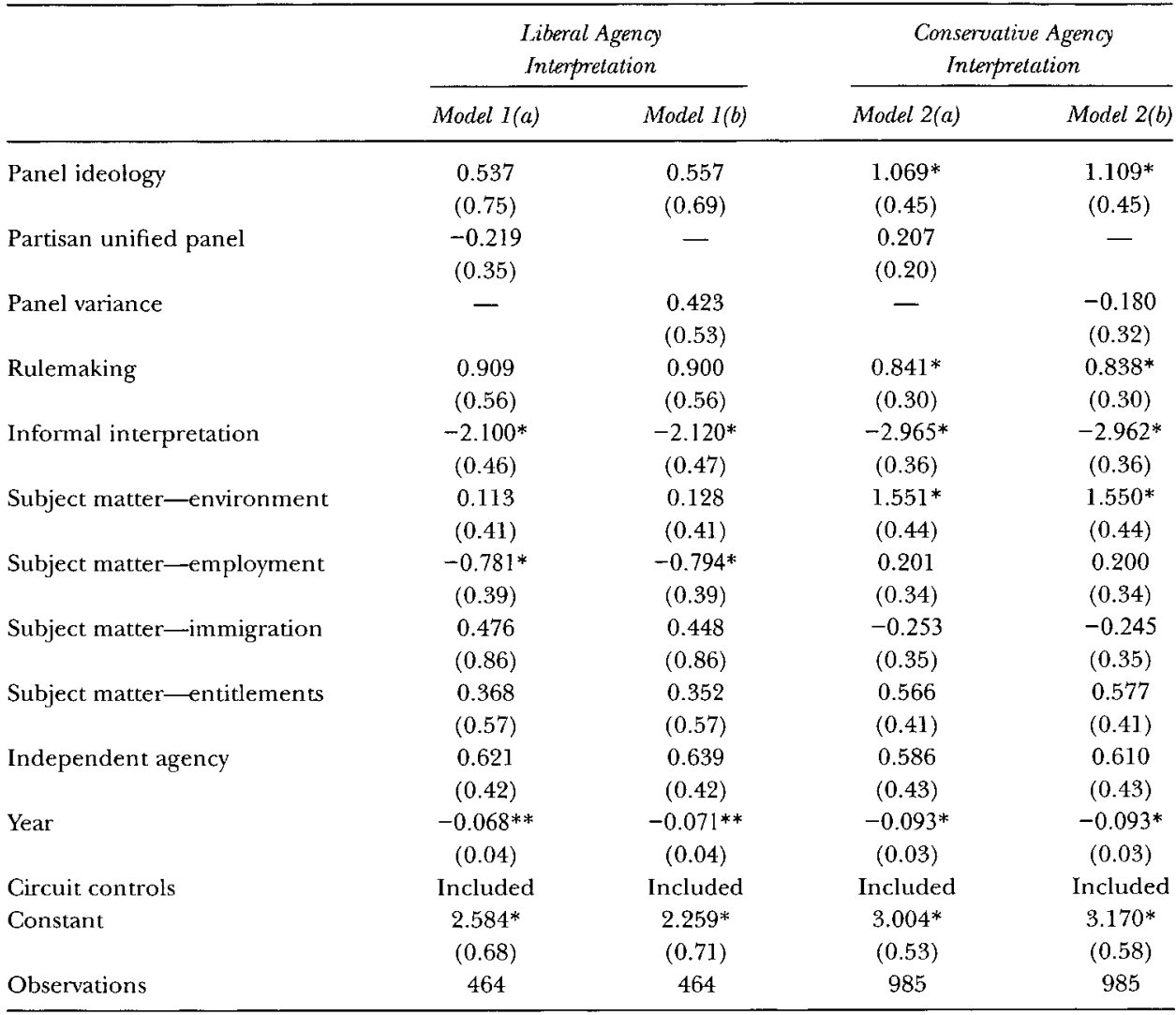

NOTE: Baseline values include Adjudication (for agency format) and Other (for subject matter). Standard errors (reported in parentheses) are robust and clustered on the individual case. ${ }^{* *} p<0.10 ;{ }^{*} p<0.05$.

using the Chevron deference framework in this circumstance is as high as 90 percent. $^{14}$

Next, we evaluate Hypothesis 2 and the potential for whistleblower effects in the use of the Cherron deference framework. Recall that we use two alternative measures to capture this potential effect, Partisan Unified Panel and Panel Variance. If they behave according to the hypothesis, Partisan Unified Panel should have a negative effect on the dependent variable (Cherron Deference) in Models 1a and 2a, and Panel Variance should have a positive effect in Models $1 \mathrm{~b}$ and $2 \mathrm{~b}$. As the results in Table 2

\footnotetext{
${ }^{14}$ One might believe that circuit judges first decide the outcome of the case before deciding on the content of the opinion and whether to apply Cheoron or a lower deference standard. To account for this possibility, we estimate an alternative specification of Models $1 \mathrm{a}$ and $2 \mathrm{a}$ with the inclusion of an additional case outcome independent variable. Doing so does not alter the substance of the key results reported in the text.
} 
Figure 1: Predicted probability that a circuit court panel will use the Cheoron deference framework based on the panel majority's ideology.

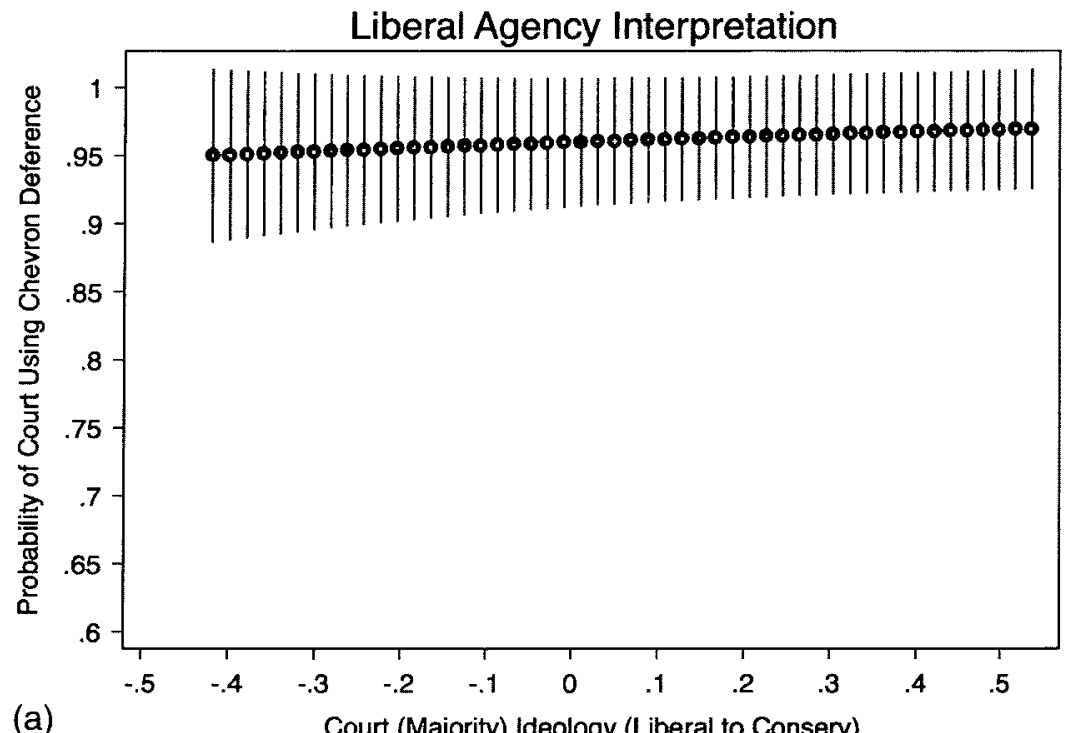

(a) Court (Majority) Ideology (Liberal to Conserv)

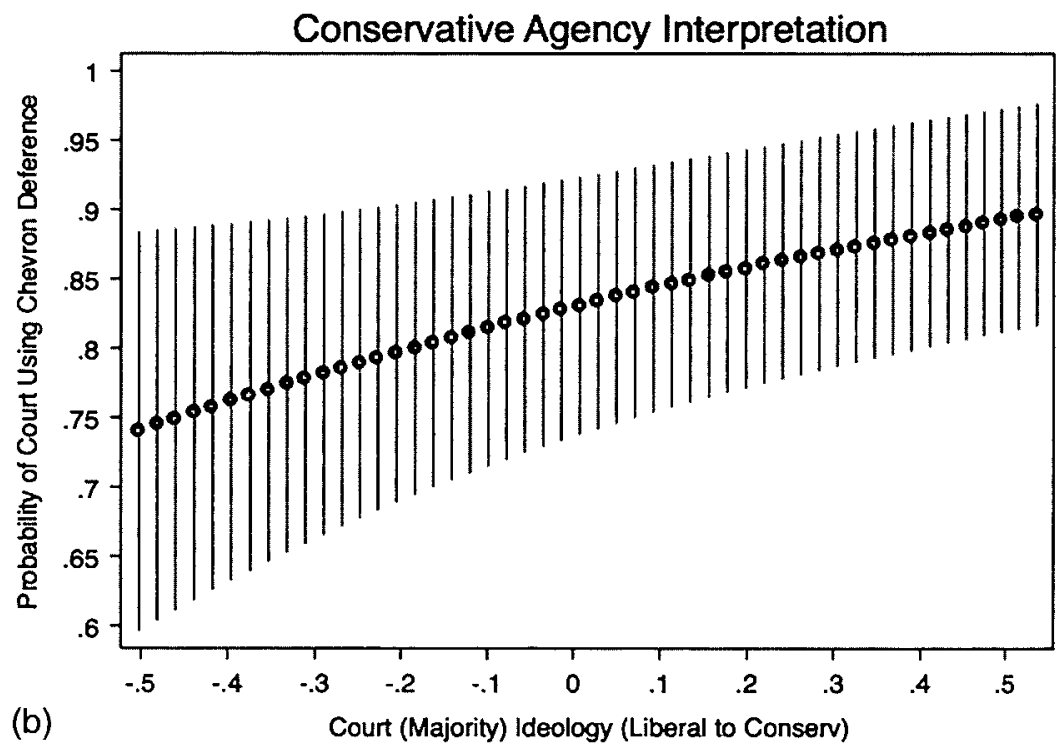

NoтE: All other values held at their mean and modal values. Vertical lines represent 95 percent confidence intervals. 
indicate, neither Partisan Unified Panel nor Panel Variance has a statistically significant effect on the likelihood of the panel using the Cherron deference framework in any of the models.

To examine Hypothesis 3, we take a further step in our statistical analysis to assess if a whistleblower effect emerges when a 2-1 panel majority is in ideological conflict with the agency's interpretation. To do this, we reestimate Models 1 and 2 with the additional inclusion of an interaction term. By interacting Panel Ideology \& Partisan Unified Panel (as well as Panel Ideology \& Panel Variance), we can more precisely assess the circumstances where two members of the panel are likely to be in ideological opposition with the agency's statutory interpretation but the third minority member of the panel may act to effectively force the panel to use the Chevron deference framework anyway. The results are reported in Table 3.

Since interactive terms are difficult to interpret substantively, we look to Figure 2's graphical depiction of the interactive effect of Panel Ideology with the panel's partisan and ideological homogeneity. The results provide no evidence to support Hypothesis 3 for either the liberal or the conservative agency interpretation subsets of data. First, looking to subfigures (a) and (b) focused on divided versus unified partisan panels, Hypothesis 3 (a) would anticipate that during times of a liberal agency interpretation, conservative panels composed 3-0 of Republican judges would be less likely to use the Cherron deference framework than panels composed of two Republican judges and one Democrat judge. As subfigure (a)'s right side makes clear, divided and unified conservative panels are indistinguishable in their Cheoron behavior. Similarly, for conservative agency interpretations, Hypothesis 3 and Partisan Unified Panel expect 3-0 Democrat judge panels to have more freedom to not use the Cheoron deference framework than 2-1 Democrat judge panels. Subfigure (c) does see the divided and unified panel lines diverging from one another as the panel ideology becomes more liberal, but that divergence is in the opposite direction as expected. Additionally, large confidence intervals indicate that any differences between the estimates for divided and unified panels are not statistically significant. The story is nearly identical for Hypothesis 3, Panel Variance, and subfigures (b) and (d): there is no difference between conservative, ideologically homogenous and heterogeneous panels in the face of a liberal agency interpretation and the downward trend for liberal panels during times of conservative agency interpretations is in the opposition direction of what would be expected.

We turn briefly to the control variables in our models. Returning to the estimations from Models 1a and 2a, we see that the agency's format or process for engaging in statutory interpretation does, at times, have an effect on whether the Chevron deference framework is provided. Informal Interpretation is statistically significant and negative (relative to the baseline of Adjudication) in Models $1 \mathrm{a}$ and 2a, and Rulemaking is significant and positive in Model 2a.

The substantive effects of these comparative agency formats are plotted in Figure 3. During times of a liberal agency interpretation (depicted in the top portion of the figure), panels are about 41 percent more likely to use the Cheoron deference framework when the agency uses rulemaking than when it uses a type of informal interpretation. Similarly, panels are approximately 36 percent more likely to use the Chevron 
Table 3: Logistic Regression Estimates for Whether the Reviewing Panel Uses the Cherron Deference Framework, with Interaction Terms

\begin{tabular}{|c|c|c|c|c|}
\hline & \multicolumn{2}{|c|}{$\begin{array}{l}\text { Liberal Agency } \\
\text { Interpretation }\end{array}$} & \multicolumn{2}{|c|}{$\begin{array}{l}\text { Conservative Agency } \\
\text { Interpretation }\end{array}$} \\
\hline & Model 3(a) & Model 3(b) & Model 4(a) & Model $4(b)$ \\
\hline Panel ideology & $\begin{array}{l}-0.210 \\
(1.08)\end{array}$ & $\begin{array}{c}0.843 \\
(0.99)\end{array}$ & $\begin{array}{c}1.446^{* *} \\
(0.75)\end{array}$ & $\begin{array}{l}0.908 \\
(0.60)\end{array}$ \\
\hline Partisan unified panel & $\begin{array}{l}-0.333 \\
(0.36)\end{array}$ & - & $\begin{array}{l}0.225 \\
(0.20)\end{array}$ & - \\
\hline Panel ideology $\times$ Partisan unified panel & $\begin{array}{l}1.186 \\
(1.34)\end{array}$ & - & $\begin{array}{c}-0.569 \\
(0.85)\end{array}$ & - \\
\hline Panel variance & - & $\begin{array}{l}0.517 \\
(0.56)\end{array}$ & - & $\begin{array}{l}-0.206 \\
(0.32)\end{array}$ \\
\hline Panel ideology $\times$ Panel variance & - & $\begin{array}{l}-0.790 \\
(1.98)\end{array}$ & - & $\begin{array}{l}0.628 \\
(1.32)\end{array}$ \\
\hline Rulemaking & $\begin{array}{l}0.920 \\
(0.56)\end{array}$ & $\begin{array}{l}0.900 \\
(0.56)\end{array}$ & $\begin{array}{l}0.840^{*} \\
(0.30)\end{array}$ & $\begin{array}{l}0.837^{*} \\
(0.30)\end{array}$ \\
\hline Informal interpretation & $\begin{array}{c}-2.109^{*} \\
(0.46)\end{array}$ & $\begin{array}{c}-2.125^{*} \\
(0.46)\end{array}$ & $\begin{array}{c}-2.972^{*} \\
(0.36)\end{array}$ & $\begin{array}{c}-2.969 * \\
(0.36)\end{array}$ \\
\hline Subject matter-environment & $\begin{array}{l}0.087 \\
(0.42)\end{array}$ & $\begin{array}{l}0.123 \\
(0.41)\end{array}$ & $\begin{array}{l}1.546^{*} \\
(0.44)\end{array}$ & $\begin{array}{l}1.549^{*} \\
(0.44)\end{array}$ \\
\hline Subject matter-employment & $\begin{array}{c}-0.793^{*} \\
(0.40)\end{array}$ & $\begin{array}{c}-0.793^{*} \\
(0.39)\end{array}$ & $\begin{array}{l}0.202 \\
(0.34)\end{array}$ & $\begin{array}{l}0.206 \\
(0.34)\end{array}$ \\
\hline Subject matter-immigration & $\begin{array}{l}0.462 \\
(0.86)\end{array}$ & $\begin{array}{l}0.435 \\
(0.86)\end{array}$ & $\begin{array}{l}-0.257 \\
(0.35)\end{array}$ & $\begin{array}{l}-0.246 \\
(0.35)\end{array}$ \\
\hline Subject matter-entitlements & $\begin{array}{r}0.416 \\
(0.57)\end{array}$ & $\begin{array}{l}0.370 \\
(0.57)\end{array}$ & $\begin{array}{l}0.568 \\
(0.41)\end{array}$ & $\begin{array}{l}0.584 \\
(0.41)\end{array}$ \\
\hline Independent agency & $\begin{array}{c}0.626 \\
(0.42)\end{array}$ & $\begin{array}{l}0.646 \\
(0.42)\end{array}$ & $\begin{array}{l}0.595 \\
(0.43)\end{array}$ & $\begin{array}{l}0.615 \\
(0.43)\end{array}$ \\
\hline Year & $\begin{array}{c}-0.070^{* *} \\
(0.04)\end{array}$ & $\begin{array}{c}-0.073^{* *} \\
(0.04)\end{array}$ & $\begin{array}{c}-0.094^{*} \\
(0.03)\end{array}$ & $\begin{array}{c}-0.094^{*} \\
(0.03)\end{array}$ \\
\hline Circuit controls & Included & Included & Included & Included \\
\hline Constant & $\begin{array}{l}2.621^{*} \\
(0.68)\end{array}$ & $\begin{array}{l}2.199^{*} \\
(0.71)\end{array}$ & $\begin{array}{l}2.994^{*} \\
(0.53)\end{array}$ & $\begin{array}{l}3.178^{*} \\
(0.58)\end{array}$ \\
\hline Observations & 464 & 464 & 985 & 985 \\
\hline
\end{tabular}

Noте: Baseline values include Adjudication (for agency format) and Other (for subject matter). Standard errors (reported in parentheses) are robust and clustered on the individual case. ${ }^{* *} p<0.10 ; * p<0.05$.

deference framework when the agency uses adjudication than when it relies on informal interpretation. For times where there is a conservative agency interpretation (bottom portion of the figure), the differences are even more notable. Holding all else equal, panels are estimated to be 59 percent more likely to use the Chevron deference framework when the agency uses adjudications than when it relies on informal interpretation. These panels are about 73 percent more likely to use the Cheoron deference framework when the agency uses rulemaking than when it uses a type of informal interpretation and 15 percent more likely when the agency uses rulemaking instead of adjudication. 
Figure 2: Predicted probability that a circuit court panel will use the Cherron deference framework based on the panel majority's ideology and the presence of a partisan or ideological whistleblower.
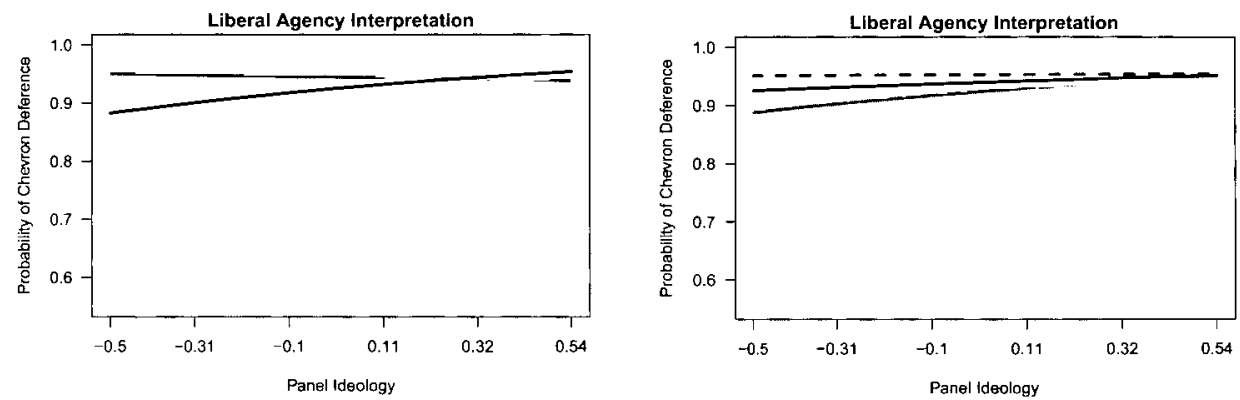

(a)

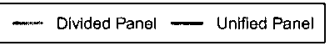

(b)

Panel ideology
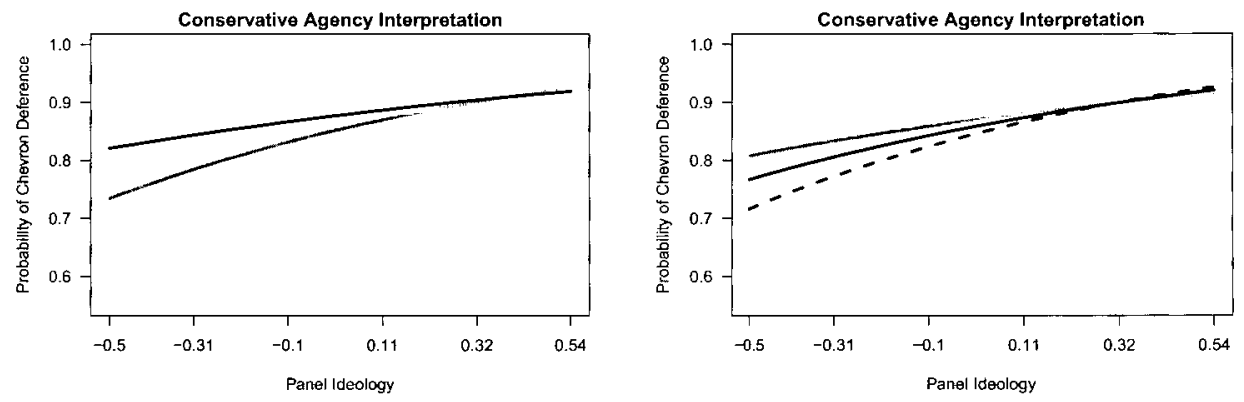

(c)

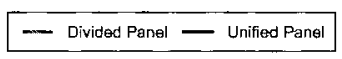

(d)

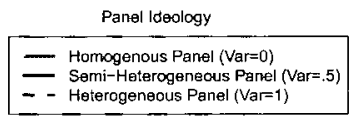

Note: All other values held at their mean and modal values.

The subject matter of the agency interpretation occasionally matters in the likelihood of Cheoron being applied. While Model la indicates that employment-related cases have a negative effect compared to other subject areas during times when the agency has a liberal interpretation, this difference is not substantively significant. Under Model 2a (conservative interpretations only), panels are approximately 16 percent more likely to use the Cheoron deference framework in environmental cases than immigration cases and 12 percent more likely to do so in environmental cases than all other subject areas not listed.

Models $1 \mathrm{a}$ and $2 \mathrm{a}$ indicate that reviewing panels do not differentially apply Chevron to Independent Agencies than to executive agencies. However, the Year variable shows a negative and significant effect for both Models 1a and 2a, indicating that Chevron is less likely to be applied as time marches on in our data (from 2003 to 2013). 
Figure 3: Change in the predicted probability that a reviewing court will use the Chevron deference framework based on different agency formats.

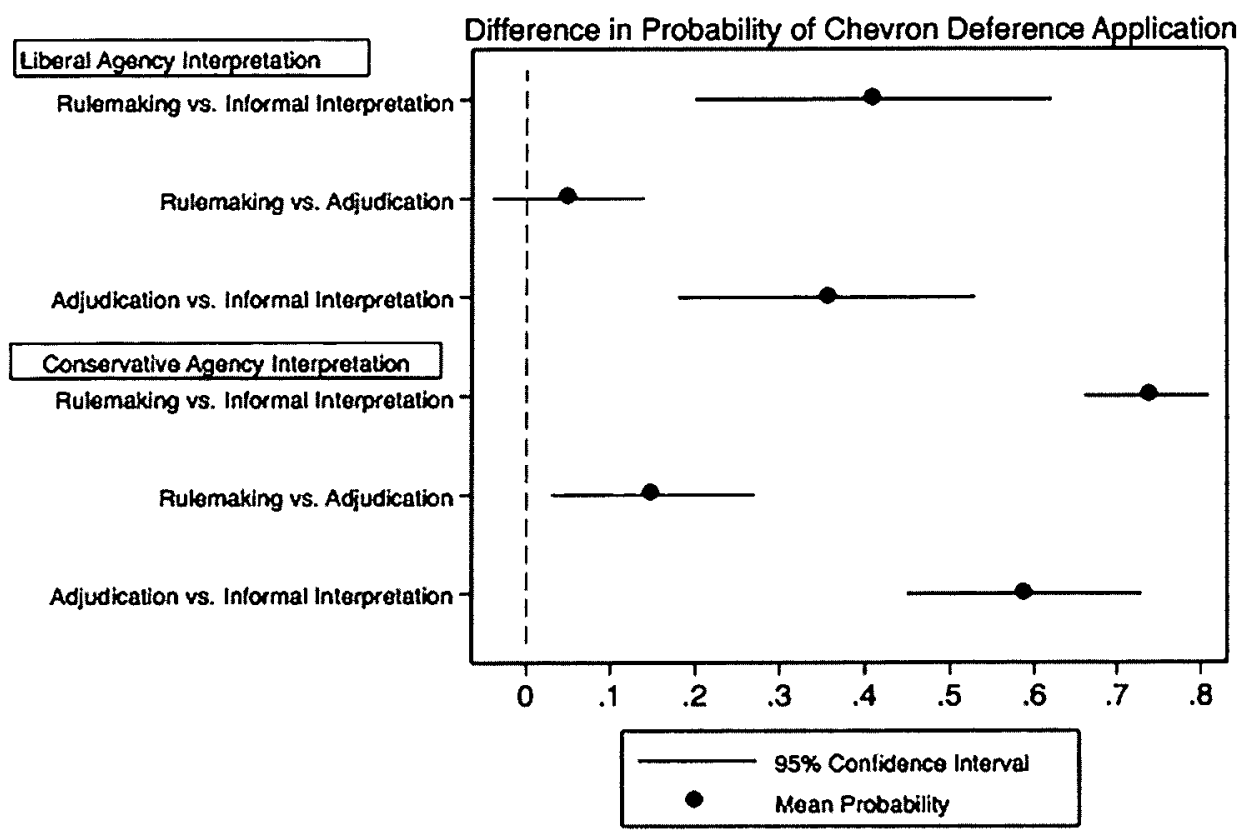

\section{Discussion And Conclusion}

In light of the recent and growing conservative calls to abandon or at least narrow Chevron deference, our findings are particularly noteworthy. As we reveal, liberal and conservative judges, on average, apply Chevrom at effectively the same high rate for liberal agency interpretations. However, when it comes to conservative agency interpretations, we find that liberal judges are less likely to apply the Cherron framework (and more likely to use a less deferential review standard) than their conservative judge counterparts-by as much as 16 percent less so than conservative judges. This finding is particularly striking as Cherron itself was the product of the Reagan Administration-a doctrine that shifted power from a liberal DC Circuit to a more conservative presidential administration.

Viewed together, our results perhaps provide additional support for conservatives' calls to revisit Cheoron deference-whether its existence altogether or how to ascertain when the doctrine applies. For instance, in Michigan v. EPA (2015), Justice Thomas has expressed constitutional concerns about Chewron deference, both under Article III of the Constitution because the doctrine displaces the court's duty to say what the law is and under Article I by facilitating excessively broad congressional delegations of law-making authority to federal agencies. Now-Justice Gorsuch expressed similar constitutional 
concerns during his time as a circuit court judge: "[T] he fact is Chevron and Brand X permit executive bureaucracies to swallow huge amounts of core judicial and legislative power and concentrate federal power in a way that seems more than a little difficult to square with the Constitution of the framers' design. Maybe the time has come to face the behemoth" (Gutierrez-Brizuela v. Lynch [10th Cir. 2016] [Gorsuch, J., concurring], at 1149). This judicial criticism, coupled with the growing scholarly criticism of Chevron deference, no doubt played a substantial role in Republicans introducing legislation to eliminate Chevron deference (Walker 2016a).

Other conservatives have stopped short of calling for Cherrom's demise and, instead, advocated for its narrowing. Chief Justice Roberts appears to be leading the charge for such narrowing, writing for the Court in King $v$. Burwell that Cheoron deference should not apply to "question[s] of deep "economic and political significance" and perhaps when the implementing agency "has no expertise in crafting [] policy of this sort" (2015:2489). Indeed, in his dissent in City of Arlington v. FCC, the Chief Justice advocated for a more-searching, context-specific Cheoron deference, arguing that "[a]n agency interpretation warrants such deference only if Congress has delegated authority to definitively interpret a particular ambiguity in a particular manner" (2013:1883). Such a context-specific narrowing of Cheoron deference is much more likely to occur than its outright elimination (Walker 2016b).

If this turns out to be true and courts are given greater discretion to avoid applying the Cheuron deference framework, the findings of this article take on even greater significance. Notably, with a more nuanced threshold inquiry comes a more open-ended, standards-based inquiry that provides courts additional discretion in deciding whether to apply the framework, even if it better captures congressional preferences as to delegated interpretive authority. That discretion would likely only exacerbate the differences that we find between conservative and liberal judges as to conservative interpretations and further frustrate the framework's purpose of removing judges from politically charged interpretations. Instead, a stronger rule-based framework (such as those proposed by Justice Scalia in his dissent in United States v. Mead Corp. (2001) and now-Judge David Barron and now-Justice Elena Kagan (Barron \& Kagan 2001) would better ensure that courts apply the Cherron framework consistently.

With Republican control of the White House (and the Senate), however, an argument could be made that it is better from conservatives' viewpoint to preserve Chevron deference. As a preliminary matter, Chewron deference in theory provides space for agency deregulatory efforts of a conservative nature. Indeed, the Chevron decision itself resulted in the Supreme Court deferring to a Reagan Administration's deregulatory effort in the environmental context. Our findings as to liberal judges and conservative agency interpretations, however, suggest that such conservative deregulatory efforts might not fare as well today, especially in a federal judiciary that has become more liberal from eight years of judicial appointments by a Democratic president.

Contrary to some evidence in prior studies, we find no evidence of "whistleblower" or disciplining effects when judges of different judicial ideologies comprised the panel. Because we focus on the choice of the doctrine rather than the case outcome, this makes our test not precisely analogous to other studies in this area. At the same time, prior empirical findings of whistleblower effects were lukewarm at best, often hampered by data limitations at 
the time (e.g., Cross \& Tiller 1998). Additionally, there may be reason to believe that Cheuronrelated whistleblowing effects are time bound. Recall that whistleblower evidence was based on earlier time periods (in the case of Cross and Tiller, 1991-1995). By contrast, this project's study focuses on more recent cases (2003-2013), all of which were decided following the Supreme Court's 2001 decision in United States $v$. Mead Corporation that clarified the continued validity of Skidmore. As a result of this renewed flexibility in the modern era, there may be less need for doctrine-based whistleblowing than was previously the case. No matter the interpretation here, it is critical that scholars continue to test for whistleblowing effects across judicial decision-making settings, subject areas, courts, and time.

We do not mean to overstate these implications from our findings. After all, liberal judges still apply the Chevron deference framework to conservative agency statutory interpretations at a somewhat high rate. Conservative agency statutory interpretations, including deregulatory efforts, could fare worse in court without Chevron deference. Although our data include every published circuit court decision that cites Chevron or Skidmore during the 11-year time period, it does not include every circuit court review of an agency statutory interpretation during the timeframe. In particular, we do not examine unpublished decisions, nor do we evaluate judicial opinions that did not cite Chevron or Skidmore. Although we think it unlikely that judges act strategically in refusing to publish a decision or refusing to cite Cheoron and Skidmore, it is a remote possibility. ${ }^{15}$

More importantly, this article does not assess whether and under which circumstances agencies ultimately prevail in court, only whether and under which circumstances circuit courts apply the Chevron framework. This threshold question nevertheless has important implications for agency outcomes in court because agency interpretations are as much as 25 percentage points more likely to prevail under Chevron deference than Skidmore deference or de novo review (Barnett \& Walker 2017a). A court's decision whether to apply the Cheoron framework also has important implications for the future development of the law. Refusal to apply the Chevron framework, in many cases, means that the court - and not the agency - is the primary, authoritative interpreter of the statutory ambiguity and, thus, the agency does not have subsequent authority to provide a different interpretation under the Supreme Court's decision in National Cable and Telecommunications Association v. Brand X Internet Services (2005). ${ }^{36}$

Our results in this arena have important implications for all of the preexisting studies examining and often finding that Cheoron's two steps are applied in ideological ways.

\footnotetext{
${ }^{15}$ As discussed in note 5 , our statistical results do not substantively change when we exclude the cases citing only Skidmore (but not Cherron) from the analysis, which provides some further support for our intuitions that courts do not strategically refuse to cite Chezron when they want to depart from its use. While prior research finds some evidence that appellate judges are strategic in their publication decisions (e.g., Vladeck \& Gulati 2005; Law 2005; Nielson \& Walker 2016), we expect that this type of strategy is much more likely to be linked to case outcomes and merits than threshold decisions.

${ }^{16}$ To be sure, sometimes a court refuses to apply Cherron deference because the agency has not utilized formal procedures, thus allowing the agency to resume its primary interpretive role by using more formalized proceedings subsequent to the judicial interpretation of the statutory ambiguity.
} 
By finding that there are also ideological effects prior to the outcome-vis-à-vis whether to apply the Cheuron deference framework at all or, instead apply Skidmore-tevel or no deference-our results confirm that prior case-outcome-focused empirical studies almost certainly undersell the ideological component of Chevron deference.

Our focus on the invocation of the Chevron deference framework also sheds important empirical light on the role of legal doctrine in cabining judicial discretion. The resulting story is a mixed one. Liberal judges' ideological preferences appear to affect their application of the Chevron deference framework, but this appears to be less true for conservative judges. As a result, our findings do not provide clear vindication for either the legal or attitudinal model as to when circuit courts invoke the Chevron framework. Viewed together, our findings underscore an earlier conclusion that "[1] egal analysis, as a distinct method of human reasoning, cannot be reduced to any methodology borrowed from another discipline. The judge brings to bear 'not only a range of personal and political preferences, but also a specialized cultural competence-his knowledge of and experience in "the law'" (Sisk et al. 1998:1500).

\section{REFERENCES}

Baldez, Lisa, Lee Epstein, \& Andrew D. Martin (2006) "Does the U.S. Constitution Need an Equal Rights Amendment?" $35 \mathrm{~J}$. of Legal Siudies 243.

Barnes Bowie, Jennifer, \& Donald R. Songer (2009) "Assessing the Applicability of Strategic Theory to Explain Decision Making on the Courts of Appeals," 62 Political Research Q. 393.

Barnett, Kent, \& Christopher J. Walker (2017a) "Cheuron in the Circuit Courts," 116 Michigan Law Rev. 1.

(2017b. "Short-Circuiting the New Major Questions Doctrine,." 70 Vanderbilt Law Rev, En Banc 147.

Barron, David J., \& Elena Kagan (2001) "Cheuron's Nondelegation Doctrine," 2001 Supreme Courl Rev. 201.

Black, Ryan C., \& Ryan J. Owens (2009) "Agenda Setting in the Supreme Court: The Collision of Policy and Jurisprudence," $71 \mathrm{~J}$. of Politics 1062.

Boyd, Christina L., Lee Epstein, \& Andrew Martin (2010) "Untangling the Causal Effects of Sex on Judging," 54(2) American J. of Political Science 389.

Caldeira, Gregory A., \& John R. Wright (1988) "Organized Interests and Agenda Setting in the U.S. Supreme Court," 82 American Political Science Rev. 1109.

Cox, Adam B., \& Thomas J. Miles (2008) "Judging the Voting Rights Act," 108(1) Columbia Lazv Rev. 1.

Cross, Frank B., \& Emerson H. Tiller (1998) "Judicial Partisanship and Obedience to Legal Doctrine: Whistleblowing on the Federal Courts of Appeals," 107 Yale Law J. 2155.

Czarnezki, Jason J. (2008) "An Empirical Investigation of Judicial Decisionmaking, Statutory Interpretation, and the Cherron Doctrine in Environmental Law," 79 Univ. of Colorado Law Rev. 767.

Eisenberg, Theodore, \& Michael Heise (2015) "Plaintiphobia in State Courts Redux? An Empirical Study of State Court Trials on Appeal," 12 J. of Empirical Legal Studies 100.

Eisenberg, Theodore, \& Stewart J. Schwab (1989) "What Shapes Perceptions of the Federal Court System?" 56 Univ. of Chicago Laxu Rev. 501.

Epstein, Lee, \& Jack Knight (1998) Choices Justices Make. Washington, DC: CQ Press.

Epstein, Lee, William M. Landes, \& Richard A. Posner (2013) The Behavior of Federal Judges: A Theoretical and Empirical Siudy of Rational Choice. Cambridge, MA: Harvard Univ. Press. 
Epstein, Lee, Andrew D. Martin, Jeffrey A. Segal, \& Chad Westerland (2007) "The Judicial Common Space," $23 \mathrm{~J}$. of Law, Economics, \& Organization 303.

Eskridge, Jr., William N., \& Lauren E. Baer (2008) "The Continuum of Deference: Supreme Court Treatment of Agency Statutory Interpretations from Cheuron to Hamdan," 96 Georgetown Law J. 1083.

Giles, Micheal W., Virginia A. Hettinger, \& Todd Peppers (2001) "Picking Federal Judges: A Note on Policy and Partisan Selection Agendas," 54 Political Research Q. 623.

Hettinger, Virginia A., Stefanie A. Lindquist, and Wendy L. Martinek (2006) Judging on a Collegial Court. Charlottesville, VA: Univ. of Virginia Press.

Kerr, Orin S. (1998) "Shedding Light on Chevron: An Empirical Study of the Cheoron Doctrine in the U.S. Courts of Appeals," 15 Yale J. on Regulation 1.

Kim, Pauline T. (2009) "Deliberation and Strategy on the United States Courts of Appeals: An Empirical Exploration of Panel Effects," 157 Univ. of Pennsylvania Law Rev. 1319.

Law, David S. (2005) "Strategic Judicial Lawmaking: Ideology, Publication, and Asylum Law in the Ninth Circuit," 73 Univ. of Cincinnali Law Rev. 817.

Lindquist, Stefanie A., \& Frank B. Cross (2005) "Empirically Testing Dworkin's Chain Novel Theory: Studying the Path of Precedent," 80 N.Y.U. Law Rev. 1156.

Miles, Thomas J., \& Cass R. Sunstein (2006) "Do Judges Make Regulatory Policy? An Empirical Investigation of Cheoron," 73 Univ. of Chicago Law Rev. 823.

Nielson, Aaron, \& Christopher J. Walker (2016) "Strategic Immunity," 66 Emory Law J. 55.

Pierce, Richard J. Jr. (1999) "Is Standing Law or Politics?” 77 North Carolina Law Rev. 1741. (2011) "What Do the Studies of Judicial Review of Agency Actions Mean?" 63 Administrative Law Rev. 77.

Priest, George L., \& Benjamin Klein (1984) "The Selection of Disputes for Litigation," $13 \mathrm{~J}$. of Legal Studies 1.

Rowland, C. K. \& Bridget Todd (1991) "Where You Stand Depends on Who Sits: Platform Promises and Judicial Gatekeeping in the Federal District Courts," $53 \mathrm{~J}$. of Politics 175.

Schuck, Peter H., \& E. Donald Elliott (1990) "To the Chetron Station: An Empirical Study of Federal Administrative Law," 1990 Duke Law J. 984.

Segal, Jeffrey A., \& Harold J. Spaeth. 2002. The Supreme Court and Attitudinal Model Revisited. New York: Cambridge Univ. Press.

Shane, Peter M., \& Christopher J. Walker (2014) "Foreword, Symposium on Cherron at 30: Looking Back and Looking Forward," 83 Fordham Law Rev. 475.

Sisk, Gregory C., Michael Heise, \& Andrew P. Morriss (1998) "Charting the Influences on the Judicial Mind: An Empirical Study of Judicial Reasoning," 73 New York Univ. Law Rev. 1377.

Staudt, Nancy C. (2004) "Modeling Standing," 79 New York Univ. Law Rev. 612.

Stephenson, Matthew C. (2010) "Statutory Interpretation by Agencies," in D. A. Farber \& A. J. O'Connell, eds., Research Handbook on Public Choice and Public Lav. Cheltenham, UK: Edward Elgar.

Sunstein, Cass R. (2000) "Deliberative Trouble? Why Groups Go to Extremes," 110 Yale Law J. 71.

Sunstein, Cass R., David Schkade, \& Lisa Michelle Ellman (2004) "Ideological Voting on Federal Courts of Appeals: A Preliminary Investigation," 90 Virginia Law Rev. 301.

Tribe, Laurence H. (1978) American Constitutional Law. Mineola: Foundation Press.

Vladeck, David C., \& Mitu Gulati (2005) "Judicial Triage: Reflections on the Debate Over Unpublished Opinions," 62 Washington E Lee Law Rev. 1667.

Walker, Christopher J. (2016a) "Courts Regulating the Regulators," RegBlog April 25. (2016b) "Toward a Context-Specific Cherron Deference," 81 Missouri Law Rev. 1095. (2018) "Attacking Auer and Cheuron Deference: A Literature Review," 16 Georgetown J. of Law \& Public Policy 103. 


\section{Cases Cited}

Bamhart v. Walton, 535 U.S. 212 (2002).

Cherron, U.S.A., Inc. v. Nat. Res. Def. Council, Inc., 467 U.S. 837 (1984).

City of Arlington v. FCC, 133 S. Ct. 1863 (2013).

Guiterrez-Brizuela v. Lynch, 834 F.3d 1142 (10th Cir.) (Gorsuch, J., concurring) (2016).

King v. Burvell, 135 S. Ct. 2480 (2015).

Michigan v. EPA, 35 S. Ct. 2699 (Thomas, J., concurring) (2015).

National Cable and Telecommunications Association v. Brand X Internet Services, 545 U.S. 967 (2005).

Skidmore v. Swift E Co., 323 U.S. 134 (1944).

United States v. Mead Corp., 533 U.S. 218 (2001). 